\title{
IMPLEMENTASI MANAJEMEN STRATEGIK DI SEKOLAH UNGGULAN SMP NEGERI 3 TUBAN
}

\author{
Muhammad Amin Amrullah \\ Sri Setyowati \\ Haris Supratno \\ Program Studi Manajemen Pendidikan Pascasarjana Universitas Negeri Surabaya \\ muhammadamrullah@mhs.unesa.ac.id
}

\begin{abstract}
Abstrak: Penelitian ini bertujuan mengetahui implementasi manajemen strategik di SMP Negeri 3 Tuban. Fokus penelitian (1) Bagaimanakah perencanaan manajemen strategik di SMP Negeri 3 Tuban yang mencakup; analisis internal, analisis eksternal, penyusunan visi, misi dan tujuan. (2) Bagaimanakah perencanaan operasional di SMP Negeri 3 Tuban yang meliputi; sasaran, kurikulum, sarana, siswa, tenaga pendidik. Penelitian ini menggunakan pendekatan kualitatif. Jenis penelitian ini dengan studi kasus yang bertujuan untuk mengevaluasi manajemen strategik di SMP Negeri 3 Tuban. Rancangan penelitian dilakukan dengan memotret fokus-fokus, mengevaluasi fokus yang ditemukan membandingkan dengan standar atau teori terkait, memberikan solusi dan diringkas dalam bentuk matrik dan gambar. Pengumpulan data mengunakan teknik wawancara, observasi dan dokumentasi. Data dianalisis dengan metode deskriptif kualitatif dengan tiga tahapan kegiatan, yaitu kondensasi data, penyajian data dan penarikan kesimpulan. Pengabsahan data menggunakan uji credibility (derjat kepercayaan) dependibility (kebergantungan), confirmability (kepastian). Hasil penelitian adalah: (1) perencanaan manajemen strategik di SMP Negeri 3 Tuban telah dilaksanakan dengan cukup baik yang mencakup: analisis internal di telah dilakukan dengan baik, analisis eksternal yang dilakukan kurang tepat, Penyusunan visi, misi dan tujuan telah dilaksnakan dengan baik. (2) Perencanaan operasional di SMP Negeri 3 Tuban telah dilaksanakan dengan baik, yang mencakup: sasaran telah dirumuskan dengan baik, kurikulum telah dipersipakan dengan baik, sarana telah dipersiapkan dengan baik, siswa telah diseleksi dengan baik, pendidik di telah di seleksi dengan baik, Pelaksanaan kegiatan pembelajaran telah dilakukan dengan baik.
\end{abstract}

Kata kunci: implementasi manajemen strategik, perencanaan strategik, perencanaan operasional dan sekolah unggulan

Abstract : The aim of this research is to find out the strategic management implementation at state Secondary School 3 Tuban. The research focus is (1) How is the strategic management planning at State Secondary School 3 Tuban, focused on internal analisys, vision. Mission and goal arragement, (2) How is the operational planning at State Secondary School 3 Tuban, focused on: goals, curruculum, tools and equipment, student, educators. The reserach approach used is qualitative. Case study in this reserach is used to evaluate the strategic management at State Secondary School 3 Tuban. While the design research isw used by taking picture of some focus, evaluating and comparing with connected theories, giving solution in the form of matrics and pictures. In other sides, to colect data, the reseracher used interview technique, observation, and documentation. All data were analized by qualitative dscriptive methode, steping three phase of activities, such as data condentation and taking conlusion. While in validating data used credibility test (dagree of belief) dependibility, and confirmability. The results of this research is: (1) The strategic management planning at State Secondary School 3 Tuban has been perfomed well including internal analisys, external analysis wasn't used exactly. While vision, mission and goal arrangement have been well with school team development. (2) The operational planning at State Secondary School 3 Tuban has been perfomed well, a well-prepared curriculum, a well-completed equipments, a good student selection, a well educator selection.

Keywords: Strategic Management Implementation, Strategic Planning, Operation Planing, and Qualified School. 
Manajemen stratejik adalah sebuah manajemen yang mengajak manusia untuk memikirkan masa depan secara sistematis sedini mungkin. Dipelopori pertama kali oleh dunia bisnis yang akhirnya mengantarkan dunia bisnis pada gerbang kejayaan, menjadikannya dilirik dan diincar oleh banyak bidang lain di luar bisnis.

Kata strategik pertama kali dipakai adalah dalam dunia peperangan. Lebih jelasnya, strategik merupakan sebuah trik yang dipakai oleh para jendral romawi dalam memimpin perang dan banyak menuai kemenangan (Jatmiko, 2003). Manajemen strategic, formulasi strategi, dan implementasinya merupakan suatu kesatuan yang penting. (Mišanková \& Kočišová, 2014)

Manajemen strategik yang merupakan faktor kunci keberhasilan suatu lembaga dalam hal perencanaan.(Akyel, KorkusuzPolat, \& Arslankay, 2012) Manajemen strategik adalah proses atau rangkaian kegiatan pengambilan keputusan yang bersifat mendasar dan menyeluruh, disertai penetapan cara melaksanakannya, yang dibuat oleh manajemen puncak dan diimplementasikan oleh seluruh jajaran di dalam suatu organisasi, untuk mencapai tujuannya (Nawawi, 2003). Dalam strategi pengambilan keputusan, strategi analisis merupakan factor yang utama. (Papulova \& Gazova, 2016)

Manajemen strategik merupakan suatu sistem yang merupakan satu kesatuan yang memiliki berbagai komponen yang saling berhubungan dan saling mempengaruhi, dan bergerak secara serentak (bersama-sama) kearah yang sama.(Moldovan, 2012) Komponen pertama adalah perencanaan strategik dengan unsur-unsurnya yang terdiri dari visi, misi, tujuan strategik. Sedang komponen kedua adalah perencanaan operasional dengan unsur-unsurnya sasaran operasional, pelaksanaan fungsi-fungsi manajemen berupa fungsi pengorganisasian, fungsi pelaksanaan dan fungsi penganggaran, kebijakan situasional, jaringan kerja (net work) internal dan eksternal, fungsi kontrol dan evaluasi serta umpan balik. Manajemen stratejik adalah roadmap bagi institusi pendidikan untuk mensukseskan sekolah. (Amoli \& Aghashahi, 2016). Salah satu kunci keberhasilah manajemen stratejik adalah kepemimpinan. (Slavik, Putnova, \& Cebakova, 2015)
Pendidikan memegang peranan penting dalam upaya peningkatan sumber daya manusia. Begitu juga sebaliknya, peningkatan kualitas pendidikan merupakan suatu proses yang harus terintegrasi dengan peningkatan sumber daya manusia (SDM). Sementara itu, kondisi SDM kita sangat rendah baik dalam konteks mutu pendidikan, dan daya saingnya. Indikator rendahnya mutu pendidikan nasional dapat dilihat pada prestasi siswa. Institusi pendidikan membutuhkan sistem manajemen yang tepat untuk mengontrol outcome mereka berjalan efektif dan efisien (Latorre-Medina \& Blanco-Encomienda, 2013)

Peningkatan mutu lembaga pendidikan/sekolah dari play group, SD, SLTP, SLTA, Universitas, bahkan ke institusi-institusi pendidikan lainnya mutlak dilakukan dalam era globalisasi ini. Dalam situasi lingkungan internal maupun eksternal yang penuh dinamika maka lembaga pendidikan diwajibkan untuk mengembangkan manajemen organisasi yang dapat memberikan pelayanan yang memuaskan kepada masayarakat pada umumnya dan pengguna jasa pendidikan (siswa dan orangtua) pada khususnya. Mengingat keberadaan pendidikan sangat ditentukan oleh kemampuan dalam memenuhi kebutuhan dan keinginan konsumen secara memuaskan.

Dalam website-nya Balitbang Depdiknas tahun 2003, menyebutkan bahwa gagasan tentang reformasi pendidikan di Indonesia menjadi sangat relevan, terutama dalam konteks penyiapan SDM yang berkualitas yang harus dimulai dengan perbaikan pendidikan pada semua jenjang dan jalur secara komprehensif meliputi perbaikan perencanaan, proses pembelajaran, dukungan alat dan sarana pembelajaran, serta perbaikan manajemen.

Fokus utama harus lebih diutamakan pada peningkatan mutu, baik proses maupun produknya, yang diarahkan pada cara mengelola sekolah yang lebih berkualitas dan efektif, antara lain melalui usaha pengembangan dan perbaikan kurikulum, sistem evaluasi, peningkatan sarana pendidikan, materi ajar, serta pelatihan guru dan tenaga kependidikan lainnya, termasuk juga perubahan pengelolaan pendidikan. Hal ini disebabkan karena pada kenyataannya, sekolah merupakan suatu lembaga terdepan untuk mencetak sumber daya manusia yang diinginkan. Berbagai pendekatan, teknik dan 
metode harus dikembangkan guna menciptakan suasana sekolah yang kondusif dan efektif agar dapat mengembangkan potensi manusia sesuai dengan karakter dan potensi yang dimilikinya.

Keunikan dari penelitian ini adalah sekolah yang digunakan sebagai obyek penelitian yaitu : SMP Negeri 3 Tuban sebagai sekolah unggulan daerah di kabupaten Tuban, sekolah pengembang pendidikan agama islam unggulan nasional, sekolah yang berbudaya lingkungan.

Urgensi dari penelitian ini adalah sekolah SMP Negei 3 Tuban di tahun 2016 telah mencapai prestasi dengan capaian nilai UN tertinggi pada tingkat kabupaten dengan nilai 9,61. Kebiasaan positif tersebut telah di targetkan setiap tahun agar selalu mendapatkan nilai tertinggi pada tingkat kabupaten melalui strategi-strategi yang telah dipersiapkan.

Fokus penelitian dalam penelitian ini adalah sebagai berikut:

1. Bagaimana perencanaan manajemen strategik di SMP Negeri 3 Tuban yang sesuai dengan standar, yang mencakup:

a. Analisis internal SMP Negeri 3 Tuban

b. Analisis eksternal SMP Negeri 3 Tuban

c. Penyusunan visi, misi dan tujuan SMP Negeri 3 Tuban

2. Bagaimana Perencanaan Operasional di SMP Negeri 3 Tuban yang sesuai dengan standar, yang meliputi:

a. Sasaran sekolah di SMP Negeri 3 Tuban

b. Kurikulum sekolah di SMP Negeri 3 Tuban

c. Sarana sekolah di SMP Negeri 3 Tuban

d. Siswa sekolah di SMP Negeri 3 Tuban

e. Tenaga pendidik/guru di sekolah SMP Negeri 3 Tuban

\section{TUJUAN PENELITIAN}

Tujuan penelitian ini adalah untuk mengetahui:

1. Bagaimana perencanaan manajemen strategik di SMP Negeri 3 Tuban yang sesuai dengan standar, yang mencakup:

a. Analisis internal SMP Negeri 3 Tuban

b. Analisis eksternal SMP Negeri 3 Tuban

c. Penyusunan visi, misi dan tujuan SMP Negeri 3 Tuban

2. Bagaimana Perencanaan Operasional di SMP Negeri 3 Tuban yang sesuai dengan standar, yang meliputi:

a. Sasaran sekolah di SMP Negeri 3 Tuban

b. Kurikulum sekolah di SMP Negeri 3 Tuban c. Sarana sekolah di SMP Negeri 3 Tuban

d. Siswa sekolah di SMP Negeri 3 Tuban

e. Tenaga pendidik/guru di sekolah SMP Negeri 3 Tuban

\section{METODE}

Metode penelitian ini menggunakan pendekatan kualitatif. Melalui pendekatan kualitatif ini dipilih untuk mengetahui secara rinci, jelas dan mendalam tentang penerapan manajemen strategik di lingkungan SMP Negeri 3 Tuban. Data tersebut mungkin berasal dari naskah, wawancara, catatan lapangan, dokumen pribadi, catatan atau memo dan dokumen resmi lainnya.

Dalam penelitian ini, peneliti turun langsung ke lapangan aktif mendengar, mengamati, bertanya, mencatat, terlibat, menghayati, berpikir, dan menarik informasi yang diperoleh di lapangan. Proses pengumpulan data dilakukan oleh peneliti sendiri sebagai instrument kunci dan dilakukan pada latar (setting) yang alamiah.

Jenis Penelitian ini tergolong studi kasus yang bertujuan untuk mengevaluasi apakah manajemen strategik di SMP Negeri 3 Tuban sudah benar dalam penyelenggaraanya atau belum.

Hal-hal yang menjadi fokus penelitian ini nanti akan dipotret terlebih dahulu, kemudian hasilnya dibandingkan dengan teori-teori terkait yang sudah ada yang dijelaskan lebih detail dalam kajian teori untuk diberikan rekomendasi atau cara bagaimana yang betul menurut teori pada fokus yang masih perlu untuk diadakan perbaikan, sedang untuk fokus yang sudah cocok dengan kriteria atau teori, maka berarti fokus itu sudah terlaksana dengan baik dan perlu dipertahankan dan dikembangkan. (Sugiyono, 2012)

Rancangan penelitian dalam penelitian ini adalah:

1. memotret fokus-fokus yang diinginkan yaitu peneliti menggambarkan kondisi sesungguhnya yang ada di lapangan secara riil tanpa ada penambahan maupun pengurangan berdasarkan fokus yang direcanakan untuk diteliti.

2. mengevaluasi fokus-fokus yang telah ditemukan dengan membandingkan pada standar atau teori-teori terkait. Artinya, dalam prosesnya nanti akan memungkinkan untuk menemukan persamaan atau perbedaan antara keadaan seungguhnya dengan standar 
yang baik, yaitu sebagaimana teori-teori yang dijabarkan dalam kajian teori.

3. memberikan solusi atau merekomendasikan atas kekurangankekurangan yang ada pada masingmasing fokus dengan tujuan memperbaiki yang sudah ada menuju standar ideal berdasarkan teori.

4. hasil evaluasi yang sudah didapat dalam penelitian ini selanjutnya diringkas dalam bentuk matrik. Matrik tersebut memberi gambaran seluruh kegiatan pada langkahlangkah evaluasi di atas, yang mana pada kolom-kolom matrik tersebut akan memuat adanya fokus-fokus yang sudah diteliti

Penelitian ini dilaksanakan di SMP Negeri 3 Tuban yang berada di Jl. Sunan Kalijaga no.1 Tuban Jawa Timur. Berdiri sejak Tahun 1977 yang memiliki Visi : Unggul, Religius, Peduli dan Berbudaya Lingkungan. Sebagai Sekolah Unggulan Daerah, Sekolah Pengembang Pendidikan Agama Islam Unggulan Nasioanal. Dan menjadi sekolah favorit masyarakat Kab.Tuban.

Penelitian dilaksanakan pada bulan September 2016 - Maret 2017.

Subjek penelitian ini adalah manajemen strategik di SMP Negeri 3 Tuban. Adapun informan penelitian ini adalah para pejabat atau pengelola beserta stakeholder sekolah SMP Negeri 3 Tuban. mereka adalah

1. Kepala sekolah SMP Negeri 3 Tuban

2. Waka Sekolah SMP Negeri 3 Tuban

3. Waka Kesiswaan

4. Waka Kurikulum

5. Siswa

Teknik pengumpulan data Dalam penelitian ini menggunakan beberapa tehnik sebagai berikut:

\section{Observasi}

Teknik observasi ini peneliti gunakan untuk mengadakan pengamatan secara langsung tentang manajemen strategik yang ada di sekolah unggulan di SMP Negeri 3 Tuban.

Dalam penelitian ini yang menjadi fokus adalah mengevaluasi manajemen strategik di SMP Negeri 3 Tuban. sehingga dalam observasi ini peneliti akan menggali data melalui sajian-sajian fokus penelitian yang berupa perencanaan strategik, perencanaan operasional dan evaluasi manajemen strategik di SMP Negeri 3 Tuban.

Dalam melakukan pengamatan ini peneliti bertindak secara langsung dan tidak dipengaruhi atau intervensi dari orang lain sehingga hasil yang diperoleh bersifat objektif dan alamiyah karena penelitian ini dilakukan secara tatap muka dengan pihak-pihak yang memiliki andil dengan SMP Negeri 3 Tuban.

\section{Wawancara}

Dalam wawancara ini peneliti mewawancarai beberapa informan yang dianggap memiliki peranan dan terlibat langsung di SMP Negeri 3 Tuban, mulai dari tingkat kepala sekolah, wakil kepala, waka kesiswaan, waka kurikulum dan siswa.

Dalam wawancara ini yang dilakukan peneliti menyusun instrumen wawancara sebagai pedoman agar informasi yang diterima dari informan bersifat kredibel dan tetap pada lingkup yang dibutuhkan dalam penelitian ini khususnya mengenai evaluasi manajemen strategik di SMP Negeri 3 Tuban dalam wawancara ini peneliti mengajukan beberapa pertanyaan yang kemudian dari jawaban yang ada dilanjutkan dengan diskusi agar pertanyaan dan jawaban yang diperoleh itu semakin tajam.

3. Dokumentasi

Teknik ini peneliti gunakan untuk mengumpulkan data yang berkaitan dengan pembahasan melalui pencatatan dokumen yang ada hubungannya dengan manajemen strategik di SMP Negeri 3 Tuban.

Teknik dokumentasi ini digunakan untuk memperoleh data laporan-laporan, foto-foto, rekaman, buku arsip dan dokumen-dokumen lainnya. Serta keunggulan dan prestasi yang pernah dicapai oleh SMP Negeri 3 Tuban.

Teknik analisis data yang dipakai dalam penelitian ini adalah analisis data deskriptif kualitatif. Aktifitas dalam analisis data yaitu:

1. Kondensasi Data (Data Condensation)

Kondensasi data merujuk pada proses memilih, menyederhanakan, mengabstrakkan, dan atau mentransformasikan data yang mendekati keseluruhan bagian dari catatancatatan lapangan secara tertulis, transkrip wawancara, dokumen-dokumen, dan materimateri empiris lainnya.

Kondensasi data dalam penelitian ini digunakan untuk menyederhanakan data yang diperoleh dari SMP Negeri 3 Tuban hal ini dilakukan tentunya data setelah diperoleh lalu dirangkum dan diambil bagian-bagian penting yang ada kaitannya dengan manajememen strategik yang ada di SMP Negeri 3 Tuban

Jadi dalam tahap anlisis data, peneliti dalam menyajikan data tidak semata-mata disajikan dalam bentuk mentah akan tetapi 
data tersebut disederhanakan dan diperjelas kembali agar pokok permasalahan dalam penelitian ini bisa jelas dan terarah untuk penelitian selanjutnya.

2. Penyajian Data

Penyajian data adalah sebuah pengorganisasian, penyatuan dari informasi yang memungkinkan penyimpulan dan aksi. Penyajian data membantu dalam memahami apa yang terjadi dan untuk melakukan sesuatu, termasuk analisis yang lebih mendalam atau mengambil aksi berdasarkan pemahaman.

Adapun penyajian data yang akan dipakai dalam penelitian ini adalah cerita fokus demi fokus tentang manajemen strategik di SMP Negeri 3 Tuban dalam bentuk teks uraian singkat yang bersifat naratif yang dilengkapi dengan gambar dan matrik.

\section{Penarikan Simpulan}

Penarikan Simpulan ini dilakukan sejak permulaan pengumpulan data. Peneliti berusaha mencari makna dari data yang diperoleh untuk disimpulkan, peneliti mencari pola-pola penjelasan, konfigurasi-konfigurasi yang mungkin, sebab akibat, proposisi dan sebagainya. Dari data yang didapat itu, peneliti mencoba mengambil simpulan apa yang belum jelas/ pasti, tetapi akhirnya menjadi semakin jelas, lebih rinci dan mengakar dengan kokoh karena data yang diperoleh semakin banyak dan mendukung.

Penarikan simpulan tersebut selanjutnya diuji kebenarannya, kekokohannya dan kecocokannya selama peenlitian berlangsung guna mendapatkan simpulan yang obyektif dan dapat dijamin validitasnya.(Cresswell, 2010)

Pengabsahan data dalam penelitian ini, peneliti akan menguji keabsahan data dengan menggunakan:

1. Credibility (Derajat Kepercayaan)

Penggunaan uji credibility ini adalah untuk memenuhi kriteria bahwa data informasi yang dilakukan, mengandung nilai kebenaran yang dapat dipercaya oleh para pembaca yang kritis dan dapat diterima oleh orang-orang (responden) yang memberikan informasi yang dikumpulkan selama penelitian berlangsung. Menurut (Riyanto, 2007) terdapat 6 macam teknik dalam menentukan derajat kepercayaan suatu hasil penelitian, namun yang dipakai dalam penelitian ini hanya 5 teknik saja sebagai barikut:
a. Persitent
Observation
(Ketekunan
Pengamatan)

Ketekunan dalam penelitian ini dilakukan dengan pengamatan secara teliti dan rinci serta berkesinambungan terhadap fokus-fokus penelitian, selanjutnya ditelaah secara rinci sampai pada suatu titik, sehingga pada pemerisaan tahap awal tampak salah satu atau seluruh faktor yang ditelaah sudah dapat difahami dengan cara pengamatan biasa. Dengan ketekunan pengamatan ini, peneliti dapat memahami lebih mendalam tentang suatu data dan menetapkan aspek-aspek mana yang penting dan yang tidak kemudian memusatkan perhatian kepada aspek-aspek yang relevan dengan fokus penelitian.

b. Prolonged Engagement (Menggunakan Waktu Yang Lama Untuk Tinggal di Kancah Penelitian)

Dalam cukup panjangnya waktu penelitian, maka peneliti akan tinggal di tempat penelitian mulai bulan Januari sampai Maret 2017 untuk melakukan pengumpulan data. Dengan memperpanjang waktu penelitian ini, diharapkan dapat membangun kepercayaan para subjek penelitian terhadap peneliti dan juga kepercayaan diri peneliti sendiri sehingga data yang terkumpul lebih valid dan dapat dipertanggung jawabkan

c. Peer Debrieffing (Diskusi Teman Sejawat)

Dalam diskusi teman sejawat, peneliti meminta masukan kepada 2 orang kolega sebagai ahli dalam masalah penelitian yaitu 1) Prof. Dr. Murtadlo M.Pd. dan 2) Dr. Karwanto M.Pd. selaku Dosen Manajemen Pendidikan Pasca Sarjana UNESA Surabaya. Mereka dapat menanyakan sekaligus memberikan masukan tentang berbagai hal terkait dengan metode, proses, serta hasil penelitian peneliti.

Teknik ini sengaja digunakan dalam penelitian, dengan maksud untuk membuat agar peneliti tetap mempertahankan sikap terbuka dan kejujuran dan untuk memberikan kesempatan awal yang baik untuk mulai menjajaki pemikiran peneliti.

d. Refrential Adequacy Checks (Cek
Kecukupan Informasi)
Cek kecukupan data informan ini dilakukan dengan cara mengarsip semua data baik yang direncanakan maupun tidak disengaja didapat selama proses penelitian, sebagai bahan referensi ketika melakukan pengecekan keabsahan data.

e. Member Checks (Cek pada anggota tim peneliti)

Pengecekan dengan anggota yang terlibat dalam proses pengumpulan data sangat 
penting dalam pemeriksaan derajat kepercayaan. Yang dicek dengan anggota yang terlibat adalah meliputi data, kategori analisis, penafsiran, dan simpulan.

Teknik ini merupakan bentuk adanya keterlibatan partisipan (subjek) untuk meriview data, interpretasi dan laporan hasil penelitian yang telah disiapkan sebelumnya oleh peneliti. Hasil penelitian dikatakan credibel jika partisipan (subjek) setuju terhadap semua laporan penelitian. Adapun yang menjadi member checks dalam penelitian ini adalah semua subjek penting yang telah terlibat dalam proses pengumpulan data penelitian.

2. Transferability (Keteralihan)

Agar hasil penelitian ini dapat ditransfer pada subjek lain, maka peneliti akan berusaha mendiskripsikan hasil penelitian ini selengkap dan serinci mungkin dengan tetap mengacu pada fokus penelitian. Penelitian ini menggunakan kriteria keteralihan, untuk memenuhi kriteria bahwa hasil penelitian yang dilakukan dalam konteks tertentu (tempat penelitian ini dilakukan) sehingga hasil penelitian ini dapat diaplikasikan pada konteks atau setting yang lain.

3. Dependibility (Kebergantungan)

Penelitian ini menggunakan kriteria kebergantungan untuk menilai apakah proses penelitian kualitatif bermutu atau tidak. Menurut (Riyanto, 2007) untuk mengecek apakah hasil penlitian kualitatif bermutu atau tidak seorang hendaknya melihat apakah si peneliti sudah hati-hati atau belum bahkan membuat kesalahan dalam : (a) Mengkonseptualisasikan rencana penelitian, (b) Mengumpulkan data, dan (c) Menginterpretasikan data atau informasi yang telah dikumpulkan dalam suatu laporan penelitian yang telah ditulis.

Cara untuk menetapkan bahwa proses penelitian dapat dipertahnkan (dependable) ialah dengan audit dependabilitas oleh auditor independen (para pembimbing) yaitu pembimbing 1 dan 2 yaitu Dr. Sri Setyowati, M.Pd dan Prof. Dr. H. Haris Supratno guna mengkaji kegiatan yang dilakukan oleh peneliti.

4. Confirmability (Kepastian)

Teknik pemeriksaan kepastian data dilakukan dengan audit kepastian yang bertujuan untuk menilai kualitas hasil penelitian. Dengan kegiatan ini dapat diketahui apakah hasil penemuan (simpulan) itu benarbenar dari data hanya usaha konstruksi peneliti.
Untuk memenuhi kriteria confirmability, maka peneliti mengajukan laporan hasil penelitian kepada semua penguji sebagai audit independen, sehingga baik proses maupun hasil penelitian dapat dipertanggung jawabkan secara ilmiah.

\section{HASIL DAN PEMBAHASAN}

Pada bab ini akan diuraikan tentang diskusi temuan penelitian yang telah diuaraikan pada bab V. Diskusi dimaksud untuk membandingkan antara fokus penelitian dengan temuan berdasarkan teori yang ada. Pembahasan temuan-temuan penelitian ini disajikan dengan mengikuti fokus penelitian.(Mulyasa, 2004) Adapun hal-hal yang akan dibahas adalah (1) Bagaimana perencanaan manajemen strategik di SMP Negeri 3 Tuban yang sesuai standar, yang mencakup: (a) analisis internal (b) analisis eksternal (c) perumusan visi, misi dan tujuan. (2) Bagaimana Perencanaan operasional di SMP Negeri 3 Tuban yang sesuai standar, yang meliputi: (a) sasaran (b) kurikulum (c) sarana (d) siswa (e) tenaga pendidik

\section{Manajemen Strategik SMP Negeri 3 Tuban \\ 1. Perencanaan Manajemen Strategik SMP Negeri 3 Tuban}

Perumusan rencana strategis sekolah SMP 3 Tuban adalah dirumuskan dalam bentuk rencana kerja sekolah dalam rentang waktu 4 Tahun dan rencana kegiatan dan anggaran sekolah dalam rentang waktu 1 Tahun. perumusan dilakukan oleh kepala sekolah bersama beserta tim pengembang sekolah dalam rapat tertutup.

\section{a. Analisis Lingkungan Internal}

Analisis internal sekolah SMP Negeri 3 Tuban dilakukan dengan menggunakan analisis SWOT. yang dilaksanakan oleh Kepala Sekolah bersama tim pengembang sekolah yang terdiri dari; Wakasek, Urusan Kurikulum, Urusan Kesiswaan, Urusan Sarpras, Urusan Humas, Ketua Komite, Bendahara, Kepala Tata Usaha, 3 Guru Senior dalam rapat tertutup 1 tahun sekali.

Analisis data internal di SMP Negeri 3 Tuban telah dilakukan dengan baik dengan melibatkan stakeholder internal sekolah. Namun, sekolah belum melakukan analisis Peluang dan Tantangan Hal ini menyebabkan rumusan yang dihasilkan kurang sistematis terserap secara maksimal. 
Analisis lingkungan internal dalam penelitian ini sesuai dengan analisis (Nawawi, Hadari, \& Hartini, 1994) bahwa menganalisa kondisi organisasi pada saat sekarang, berupa kekuatan, kelemahan, peluang dan hambatan, yang harus diketahui secara tepat untuk merumuskan Renstra yang berjangka panjang.

analisis internal di SMP Negeri 3 Tuban telah dilakukan dengan baik dengan melibatkan stakeholder internal sekolah yaitu kepala sekolah bersama tim pengembang sekolah. Namun analisis internal kurang tersusun dengan sitematis Jika dalam analisis internal dilakukan secara sistematis dan kritis, akan melahirkan isu-isu strategis sebagai sumber sasaran dan program prioritas.

Cara memperbaikinya adalah dalam melakukan analisis internal perlu disusun secara sistematis dan tertata sehingga hasil analisis internal terkait kelebihan, kelemahan, peluang dan ancaman dapat diketahui dengan mudah.

\section{b. Analisis Eksternal}

Analisis eksternal di SMP Negeri 3 Tuban dalam pelaksanaanya dilakukan dengan rapat tertutup bersama tim pengembang sekolah

Analisis eksternal di SMP Negeri 3 Tuban dilakukan dengan menganalisis komponen / fungsi dan faktornya dari setiap sasaran untuk 1 (Satu) Tahun dimana dalam hal ini ada 7 sasaran

a) Mengembangkan kurikulum untuk menghasilkan mutu lulusan yang unggul;

(1) Dana : Untuk pengembangan kurikulum

(2) Komite Sekolah : Dukungan untuk pengembangan kurikulum

b) Mengembangkan potensi non akademik peserta didik melalui kegiatan Ekstrakurikuler;

(1) Dana : Dukungan pengembangan potensi

(2) Komite sekolah : Dukungan pengembangan sarana dan pelatih

(3) Pelatih Mitra : Kerjasama dengan guru penjasorkes, pola mitra

c) Menciptakan lingkungan akademik yang didukung perangkat pembelajaran modern;

(1) Dana : Pengadaan perangkat modern

(2) Komite sekolah : Dukungan pengembangan perangkat

d) Mengembangkan pengelolaan keuangan yang transparan, akuntabel, dan demokratis;
(1) Dana : Dukungan terhadap pengelolaan dana berbasis TAD (Transparansi, Akuntabilitas, dan Demokratis)

(2) Komite Sekolah : Dukungan dan kontrol terhadap pengelolaan keuangan berbasis TAD.

e) Mengembangkan citra sekolah berkarakter dan religius culture;

(1) Dana : Dukungan pengembangan program

(2) Komite Sekolah : Dukungan terhadap kebijakan

(3) Nara Sumber : Kapabilitas yang dibutuhkan

f) Menciptakan lingkungan sekolah sehat, asri, indah dan Menyenangkan;

(1) Dana : kegiatan pengembangan lingkungan

(2) Komite sekolah : Dukungan untuk pengembangan lingkungan

(3) Disdikpora : Dukungan kebijakan

(4) BLH (Badan Lingkungan Hidup) : pelatihan lingkungan

g) Mengembangkan kepedulian terhadap kelestarian lingkungan, pencegahan pencemaran, dan kerusakan lingkungan;

(1) Dana : Dukungan terhadap kepedulian lingkungan

(2) Komite Sekolah : Dukungan pengembangan

(3) BLH : kerjasama / pembinaan

(4) Instansi terkait : Kerja / dukungan pengembangan

Kesimpulannya

Analisis eksternal yang dilakukan di SMP Negeri 3 Tuban kurang tepat, karena analisis hanya komponen dan fungsi pada setiap sasaran yang telah di tentukan.

Padahal menurut Nawawi (2003: 158-159) Analisis lingkungan eksternal adalah menganalisa lingkungan sekitar organisasi baik dekat maupun jauh. Untuk lingkungan dekat adalah mencakup lingkungan operasional, sedang lingkungan jauh adalah mencakup lingkungan nasional dan internasional.

Evaluasinya adalah Analisis data eksternal yang dilakukan di SMP Negeri 3 Tuban kurang tepat, karena dalam menganlisis hanya sebatas komponennya (lingkungan operasional) saja dan belum mencakup lingkungan jauh mencakup lingkungan nasional dan internasional.

Cara memperbaikinya adalah dalam melakukan analisis eksternal SMP Negeri 3 
Tuban lebih dikembangkan pada lingkungan nasional dan global.

\section{c. Visi, Misi dan Tujuan}

Visi misi dan tujuan SMP Negeri 3 Tuban dirumuskan lembaga sendiri oleh kepala sekolah bersama tim pengembang sekolah dengan tetap mengacu pada visi misi dan tujuan pada dinas pendidikan.

Adapun visi dari SMP Negeri 3 Tuban adalah :" Unggul, Religius, Peduli, dan Berbudaya Lingkungan”.

Berdasarkan visi tersebut SMP Negeri 3

Tuban mengemban misi sebagai berikut:

1) Mewujudkan lulusan SMP Negeri 3 Tuban yang unggul dalam prestasi akademik dan non-akademik sesuai dengan Standar Kompetensi Lulusan yang unggul dan religius.

2) Mewujudkan pengembangan kurikulum SMP Negeri 3 Tuban yang adaptif dan proaktif sebagai landasan operasional pendidikan.

3) Mewujudkan proses pembelajaran inovatif dengan berbagai variasi pendekatan, metode, yang menyenangkan, kreatif dan komunikatif dengan sistem penilaian yang berbasis IT.

4) Mewujudkan pengembangan profesionalisme bagi pendidik dan tenaga kependidikan dengan kemampuan dan kesanggupan kerja tinggi.

5) Mewujudkan fasilitas (sarana-prasarana) pembelajaran yang berbasis IT, multimedia sistem sesuai dengan SNP dan kultur sekolah untuk mendukung keberhasilan pembelajaran.

6) Mewujudkan tata kelola sekolah yang menjamin keterlaksanaan dan keberhasilan manajemen partisipatif sebagai sekolah yang efektif dan demokratis

7) Mewujudkan pembiayaan pendidikan sesuai dengan Standar Pembiayaan dalam SNP plus, dengan membangun kemitraan dan penguatan dengan stakeholder.

8) Mewujudkan sekolah peduli tradisi serta melestarikan dan menghargai keragaman tradisi, seni dan budaya bangsa.

9) Mewujudkan sekolah peduli dan berbudaya lingkungan dalam pelestarian, perlindungan, dan pengelolaan lingkungan hidup.

Untuk mendukung terlaksananya misi tersebut, maka SMP Negeri 3 Tuban telah merumuskan beberapa tujuan antara lain:
1) Terwujudnya lulusan SMP Negeri 3 Tuban yang unggul dalam prestasi akademik dan non-akademik sesuai dengan Standar Kompetensi Lulusan yang unggul dan religius.

2) Terwujudnya pengembangan kurikulum SMP Negeri 3 Tuban yang adaptif dan proaktif sebagai landasan operasional pendidikan.

3) Terwujudnya proses pembelajaran inovatif dengan berbagai variasi pendekatan, metode, yang menyenangkan, kreatif dan komunikatif dengan sistem penilaian yang berbasis IT.

4) Terwujudnya pengembangan profesionalisme bagi pendidik dan tenaga kependidikan dengan kemampuan dan kesanggupan kerja tinggi.

5) Terwujudnya fasilitas (sarana-prasarana) pembelajaran yang berbasis IT, multimedia sistem sesuai dengan SNP dan kultur sekolah untuk mendukung keberhasilan pembelajaran.

6) Terwujudnya tata kelola sekolah yang menjamin keterlaksanaan dan keberhasilan manajemen partisipatif sebagai sekolah yang efektif dan demokratis

7) Terwujudnya pembiayaan pendidikan sesuai dengan Standar Pembiayaan dalam SNP plus, dengan membangun kemitraan dan penguatan dengan stakeholder.

8) Terwujudnya sekolah peduli tradisi serta melestarikan dan menghargai keragaman tradisi, seni dan budaya bangsa.

9) Terwujudnya sekolah peduli dan berbudaya lingkungan dalam pelestarian, perlindungan, dan pengelolaan lingkungan hidup.

Perumusan visi, misi dan tujuan di SMP Negeri 3 Tuban telah dilakukan dengan baik. Perumusan visi ditetapkan bersama tim pengembang sekolah dalam rapat tertutup. Waktu perumusan visi, misi dan tujuan dilaksanakan pada saat awal jabatan pimpinan yang baru sekitar tahun 2015 SMP Negeri 3 Tuban mengalami revisi visi,misi dan tujuan karena merasa perlu dirubah visi misi yang lama dengan pertimbangan terlalu panjang dan tidak mudah dipahami.

Setelah visi, misi dan tujuan dirumuskan selanjutnya di sosialisasikan pada semua warga sekolah. Sosialisasi dilakukan dalam kegiatan upacara, rapat pleno orang tua, rapat 
dewan guru, dan dalam bentuk slogan dan web.

Perumusan visi di SMP Negeri 3 Tuban ini sejalan dengan perumusan visi Komariah (2006: 91-92), bahwa langkah-langkah yang harus ditempuh dalam membuat visi adalah Penciptaan Visi. Visi adalah tercipta dari kreativitas pikir pemimpin sebagai refleksi profesionalisme dan pengalaman pribadi atau sebagai hasil elaborasi emikiran mendalam dengan pengikut atau personal lain, yaitu berupa ide-ide ideal tentang cita-cita organisasi di masa depan yang ingin diwujudkan bersama.

Perumusan misi pada penelitian ini sudah mengacu pada rumusan visi yang sudah ditetapkan sebelumnya. Bahwa misi adalah jawaban atas pertanyaan "apa kegiatan yang sedang atau segera dilaksanakan secara operasional di lingkungan organisasi".

Perumusan Tujuan pada penelitian di SMP Negeri 3 Tuban sesuai dengan teori (Akdon, 2007) bahwa tujuan merupakan jawaban dari apa (what) yang secara khusus harus dicapai dan kapan (when). Pencapaian tujuan dapat menjadi tolok ukur untuk menilai kinerja organisasi.

Berdasarkan data yang telah didapat oleh peneliti selama proses penelitian, maka evaluasinya adalah Perumusan visi, misi dan tujuan di SMP Negeri 3 Tuban sudah dilaksanakan dengan baik, karena dalam pelaksanaannya sudah melibatkan stakeholder sekolah yaitu tim pengembang sekolah dan hasil dari rumusan visi, misi dan tujuan tersebut telah disosialisasikan pada semua warga sekolah. Namun demikian masih ada yang perlu diperbaiki saat merumuskan misi agar kalimatnya sederhana dan mudah diingat.

\section{Perencanaan Operasional di SMP Negeri 3 Tuban}

Perencanaan operasional di SMP Negeri 3 Tuban adalah dapat dilihat pada Rencana Kegiatan dan Anggaran Sekolah yang dilaksnakan dengan Pertama; Analisis Lingkungan Operasional Sekolah baik secara makro seperti kondisi lingkungan sosial masyarakat yang rentan dengan perubahan politik, dan secara mikro, lingkungan opersional pendidikan di kabupaten Tuban sebagai kota religi, yakni salah satu kota "wali sembilan". Kedua; Analisis Situasional (Kondisi) Sekolah Saat Ini baik dari segi SDM (kompetensi guru, kepala sekolah, dan tenaga kependidikan) Fasilitas (kelengkapan bukubuku pelajaran, referensi, teks penunjang dan IT) Kurikulum (metode dan bahan ajar). Ketiga; SMP Negeri 3 Tuban yang dikelola oleh pemerintah kabupaten Tuban untuk senantiasa melakukan terobosan dalam meningkatkan mutu pendidikan dalam rangka mewadahi dan memfasilitasi peserta didik untuk bisa dan mampu bersaing di era yang kompetitif ini.

\section{a. Sasaran}

Tujuan yang telah ditetapkan, dijabarkan lebih spesifik dalam bentuk sasaran. Sasaran adalah hasil yang ingin dicapai/ diperoleh dalam kurun waktu tertentu, yang realistic dan dapat diukur tingkat pencapaiannya berdasarkan indikator kinerja tertentu yang disebut indikator kinerja sasaran. Sebagai penjabaran dari tujuan, maka sasaran harus selaras dengan tujuan. (Pidarta, 2011)

Di SMP Negeri 3 Tuban sasaran dituangkan dalam Rencana Kegiatan dan Anggaran Sekolah (RKAS) dan disusun dalam bentuk sasaran tahunan yaitu sasaran yang ingin dicapai dalam kurun waktu 1 tahun. Adapun sasaran yang ada di SMP Negeri 3 adalah:

1. Mengembangkan kurikulum untuk menghasilkan mutu lulusan yang unggul;

2. Mengembangkan potensi non akademik peserta didik melalui kegiatan ekstrakurikuler;

3. Menciptakan lingkungan akademik yang didukung perangkat pembelajaran modern;

4. Mengembangkan pengelolaan keuangan yang transparan, akuntabel, dan demokratis;

5. Mengembangkan citra sekolah berkarakter dan religius culture;

6. Menciptakan lingkungan sekolah sehat, asri, indah dan menyenangkan;

7. Mengembangkan kepedulian terhadap kelestarian lingkungan, pencegahan pencemaran, dan kerusakan lingkungan.

Sasaran di SMP Negeri 3 Tuban secara umum telah dirumuskan dengan baik dan telah memenuhi ciri sasaran yang baik yaitu SMART. Di SMP Negeri 3 Tuban sasaran disusun dalam bentuk sasaran tahunan adalah sasaran yang ingin dicapai dalam kurun waktu 1 tahun. Berdasarkan dokumentasi, peneliti melihat adanya kesesuaian antara misi dan tujuan dengan sasaran di SMP Negeri 3 Tuban, hal itu sesuai dengan teori (Akdon, 2007) yang mengatakan bahwa tahapan penyusunan sasaran yaitu: 
1.) Review misi dan tujuan

2.) Tetapkan hasil yang diinginkan

3.) Tetapkan suatu kerangka waktu bagi pencapaian hasil, dan

4.) Membangun akuntabilitas

Evaluasinya adalah sasaran di SMP Negeri 3 Tuban telah dirumuskan dengan baik dan telah memenuhi ciri sasaran yang baik yaitu SMART.

Cara memperbaikinya adalah dengan lebih mengoptimalkan cara mencapai sasaran dari segala aspek yang berhubungan.

\section{b. Kurikulum}

Kurikulum yang digunakan di SMP Negeri 3 Tuban adalah kurikulum 2013 yang mengacu pada Standard Nasional Pendidikan (SNP) dengan ditambah Dua muatan tambahan yaitu pendidikan lingkungan hidup dan bahasa arab dan BTQ (Baca Tulis Qur'an) kelas 7 dan 8.

Strategi pembelajaran di SMP Negeri 3 Tuban dengan menggunakan pendekatan CTL : Contectual Teaching Learning dan PAIKEM : Pembelajaran Aktif, Inovatif, Kreatif, Efektif, Menyenangkan.

Proses pembelajaran dilaksanakan indoor dan outdoor untuk 6 mapel. Pembelajaran indoor dilaksanakan diruangan kelas, laboratorium, perpustakaan sedangkan pembelajaran outdoor dilaksanakan diluar ruangan seperti lingkungan taman sekolah, lapangan, sesuai mapel yang diajarkan.

Dalam mepersiapkan pelaksanaan Ujian Nasional SMP Negeri 3 Tuban telah memiliki upaya untuk peningkatan nilai UN dengan menerapkan 3 tahap strategi bimbingan belajar yaitu intensif, super intensif, dan super-super intensif.

Penyusunan kurikulum di SMP Negeri 3 Tuban telah dilakukan dengan baik dengan mengacu pada SNP dengan ditambah aspek pengembangan budaya sekolah dan pengembangan budaya lingkungan sekolah.

Strategi pembelajaran yang diterapkan di SMP Negeri 3 Tuban menggunakan CTL. Yang penekanan pada siswa belajar melalui "mengalami" bukan "menghafal" hal ini sesuai dengan teori (Riyanto, 2007) yang mengutarakan CTL. Adalah sebuah strategi belajar yang tidak mengharuskan siswa untuk menghafalkan fakta-fakta, tetapi mendorong siswa mengkonstruksikan pengetahuan di benak mereka sendiri.

Sedangkan Pembelajaran PAIKEM difokuskan pada pengaktifan dan pengembangan kreatifitas siswa. Hal tersebut sesuai dengan teori (Hartono, 2012) yang mengatakan bahwa pembelajaran PAIKEM dirancang hendaknya dapat mengaktifkan peserta didik, mengembangkan kreativitas yang pada akhirnya efektif, akan tetapi tetap menyenangkan bagi para peserta didik. .

Evaluasinya adalah kurikulum pembelajaran di SMP Negeri 3 Tuban telah dipersiapkan dengan baik yaitu dengan menambah dua muatan tambahan, strategi pendekatan dan proses pembelajaran yang diterapkan juga sudah baik, serta upaya yang dilakukan untuk meningkatkan nilai dalam Ujian Nasional juga telah dipersiapkan dengan baik.

Cara memperbaikinya adalah kurikulum pembelajaran yang sudah dipersiapkan dengan baik perlu dipertahankan dan senantiasa di update sesuai dengan perkembangan teknologi, kebijakan pemerintah dan teori yang berkembang.

\section{c. Sarana}

SMP Negeri 3 Tuban senantiasa berusaha untuk meningkatkan sarana dan prasarana guna menunjang kenyamanan proses kegiatan belajar mengajar agar siswa lebih maksimal dalam menyerap pembelajaran. Terbukti dengan adanya penambahan sarana dan pra sarana dari tahun ke tahun.

Penyiapan sarana dan prasarana di SMP Negeri 3 Tuban telah dilakukan dengan baik, yaitu senantiasa berupaya meningkatkan kuantitas dan kualitas sarana dan prasarana untuk menunjang ketercapaian proses kegiatan belajar mengajar.

Secara umum penyediaan sarana dan pra sarana di SMP Negeri 3 Tuban telah dilaksanakan dengan baik. Kuantitas dan kualitas SMP Negeri 3 Tuban senantiasa diperbaiki dan ditingkatkan. Hal ini sesuai dengan teori (Hasibuan, 2003) bahwa Penyediaan tempat dan alat-alat harus didasarkan pada prinsip ekonomi serta berpedoman pada sasaran yang ingin dicapai.

Evaluasinya adalah Terdapat beberapa sarana yang pemberdayaannya kurang dimaksimalkan sehingga kegunaannya juga kurang maksimal.

Cara memperbaikinya adalah Kepala Sekolah hendaknya memberi perhatian lebih pada sarana yang kegunaannya kurang maksimal berikut cara pengelolaannya.

\section{d. Siswa}

Proses seleksi penerimaan siswa di SMP negeri 3 Tuban dilaksanakan melalui beberapa tahapan. Pertama adalah seleksi ujian sekolah 
/ NUN SD/MI dari mapel Matematika, IPA, B.Indonesia minimal 7,50 memiliki prosentase pembobotan 40\%. Kedua adalah seleksi akademik dengan test tulis dari 4 mapel bidang studi terdiri Matematika, IPA, B.indonesia, Pengetahuan umum (PKN dan IPS) memiliki prosentase pembobotan $50 \%$. Ketiga adalah seleksi adminstrasi dalam bentuk nilai prestasi akademik/nonakademik memiliki prosentase pembobotan $10 \%$.

Penentuan peserta didik di SMP Negeri 3 Tuban telah dilakukan dengan baik, yaitu dengan menggunakan sistem seleksi pada saat penerimaan peserta didik baru melalui seleksi nilai ujian nasional (NUN) SD/MI, test tulis dan prestasi yang semuanya itu dilakukan untuk mencari input siswa yang unggul agar menghasilkan output siswa yang unggul. Jumlah kelasnya pun juga dibatasi maksimal 30 siswa sehingga mendukung tercapainya efektifitas kegiatan belajar mengajar.

Seleksi penerimaan siswa yang diselenggarakan oleh SMP Negeri 3 Tuban adalah berdasarkan NUN SD/MI memiliki prosentase $40 \%$, Seleksi akademik secara tulis dari 4 mapel bidang studi terdiri Matematika, IPA, B.indonesia, Pengetahuan umum (PKN dan IPS) memiliki prosentase 50\%, Seleksi adminstrasi dalam bentuk nilai prestasi akademik/nonakademik memiliki prosentase pembobotan $10 \%$ semua dilakukan untuk mencari input siswa yang unggul agar menghasilkan output yang unggul.

Seleksi penerimaan siswa di SMP Negeri 3 Tuban telah sesuai dengan teori (Mujiarto, 2001) yang mengatakan bahwa klarifikasi sekolah unggulan terdiri dari tiga tipe salah satunya adalah "ditandai dengan keunggulan input siswa sehingga walaupun proses belajar mengajarnya tidak luar biasa, maka dugaan kita lulusannya tetap akan bermutu unggul".

Evaluasinya adalah seleksi penerimaan siswa yang dilakukan oleh SMP Negeri 3 Tuban telah dilaksanakan dengan baik.

Cara memperbaikinya adalah dengan mempertahankan strategi yang telah dilakukan dan senantiasa menginovasi dan mengupdate strategi yang berkembang pada sekolahsekolah unggulan.

\section{e. Pendidik}

Tenaga Pendidik di SMP Negeri 3 Tuban terdiri dari dua unsur yaitu: Pertama dari pemerintah Pegawai Negeri Sipil (PNS) dan yang Kedua dari Guru Tidak Tetap (GTT).
Adapun proses penerimaan pendidik di SMP Negeri 3 Tuban adalah sebagai berikut:

1) Jalur PNS, dari pemerintah yang ditempatkan di SMP Negeri 3 Tuban .

2) Jalur non-PNS (GTT), dengan cara megajukan permohonan sebagai pegawai SMP Negeri 3 Tuban, langkah selanjutnya mengikuti test seleksi meliputi: 1 . wawancara (talenta), 2. Test tulis dan gambar (Kepribadian), 3. Praktek (komputer) setelah mingikuti test akan diberi penilaian oleh pihak sekolah. jika sudah diterima maka sekolah akan memberikan surat penerimaan sebagai pegawai tidak tetap.

Proses rekrutmen dan seleksi guru di SMP Negeri 3 Tuban telah dilakukan dengan baik, karena didasarkan pada kemampuan objektif dan bukan faktor saudara atau kawan.

Pemilihan pendidik di SMP Negeri 3 Tuban telah dilakukan dengan baik, obyektif dan berbasis kompetensi. seleksi guru memperhatikan kompetensi akademik dan kemampuan bidang studi, keterampilan berkomunikasi, dan kemampuan pedagogis.

Evaluasinya adalah proses rekrutmen dan seleksi tenaga pendidik di SMP Negeri 3 Tuban telah dilakukan dengan baik, meskipun masih adanya guru yang tidak sesuai dengan latar belakang pendidikannya.

Cara memperbaikinya adalah dengan memberikan peluang, kesempatan dan biaya kepada guru yang masih belum sesuai dengan latar belakang pendidikan (keahlian) dengan tugas mengajar untuk melaksanakan study lagi menyesuaikan dengan bidang study yang diampunya.

\section{PENUTUP}

\section{Kesimpulan}

1. Perencanaan manajemen strategik di SMP Negeri 3 Tuban yang mencakup:

a. Analisis internal di SMP Negeri 3 Tuban telah dilakukan dengan baik.

b. Analisis eksternal di SMP Negeri 3 Tuban yang dilakukan kurang tepat.

c. Penyusunan visi, misi dan tujuan SMP Negeri 3 Tuban telah dilaksnakan dengan baik.

2. Perencanaan Operasional di SMP Negeri 3 Tuban telah dilaksanakan dengan baik, yang meliputi:

a. Sasaran di SMP Negeri 3 telah dirumuskan dengan baik. 
b. Kurikulum di SMP Negeri 3 Tuban telah dipersipakan dengan baik.

c. Sarana di SMP Negeri 3 Tuban telah dipersiapkan dengan baik.

d. Siswa di SMP Negeri 3 Tuban telah diseleksi dengan baik.

e. Pendidik di SMP Negeri 3 Tuban telah di seleksi dengan baik.

\section{Saran}

Perencanaan strategik merupakan suatu usaha team. Meskipun perencanaan strategik dimulai dari puncak, para pemimpin organisasi seyogyanya mencari masukan-masukan (input) dari manajer, supervisor, yang mengetahui pelayanan dan pelanggan terbaik. Team perencanaan yang terlibat dalam proses perencanaan staretgik terdiri dari orang-orang yang memiliki tanggung jawab untuk mencapai bagian dari rencana strategik, dan ukuran dari team ini akan bervariasi tergantung pada ukuran dan kompleksitas dari organisasi.

\section{DAFTAR RUJUKAN}

Akdon. (2007). Strategic Management For Educational Management (Manajemen Strategik Untuk Manajemen Pendidikan. Bandung: Alfabeta.

Akyel, N., KorkusuzPolat, T., \& Arslankay, S. (2012). Strategic Planning in Institutions of Higher Education: A Case Study of Sakarya University. Procedia - Social and Behavioral Sciences, 58, 66-72. https://doi.org/10.1016/j.sbspro.2012.09.9 79

Amoli, S. J., \& Aghashahi, F. (2016). An Investigation on Strategic Management Success Factors in an Educational Complex. Procedia - Social and Behavioral Sciences, 230(May), 447-454. https://doi.org/10.1016/j.sbspro.2016.09.0 56

Cresswell, J. W. (2010). Research design (Pendekatan kualitatif, kuantitatif dan mixed). Yogyakarta: Pustaka Pelajar.

Hartono. (2012). PAIKEM. Riau: Zanafa Publishin.

Hasibuan, M. P. (2003). Manajemen Sumber Daya Manusia. Jakarta: Bumi Aksara.

Jatmiko. (2003). Manajemen Stratejik. Malang: UMM Press.
Latorre-Medina, M. J., \& Blanco-Encomienda, F. J. (2013). Strategic Management as Key to Improve the Quality of Education. Procedia - Social and Behavioral Sciences, 81, 270-274. https://doi.org/10.1016/j.sbspro.2013.06.4 26

Mišanková, M., \& Kočišová, K. (2014). Strategic Implementation as a Part of Strategic Management. Procedia - Social and Behavioral Sciences, 110, 861-870. https://doi.org/10.1016/j.sbspro.2013.12.9 31

Moldovan, L. (2012). Integration of Strategic Management and Quality Assurance in the Romanian Higher Education. Procedia Social and Behavioral Sciences, 58, 1458-1465.

https://doi.org/10.1016/j.sbspro.2012.09.1 132

Mujiarto. (2001). Sekolah Unggul. Surabaya: Duta Graha Pustaka.

Mulyasa, E. (2004). Manajemen Berbasis Sekolah, Konsep, Strategi dan Implementasi. Bandung: Rosdakarya.

Nawawi, H. (2003). Manajemen Strategik Organisasi Non Profit Bidang Pemerintah. Yogyakarta: Gajah Madha Univesity Press.

Nawawi, Hadari, \& Hartini, M. (1994). Kebijakan Pendidikan Di Indonesia Ditinjau Dari Sudut Hukum. Yogyakarta: Gajah Madha Univesity Press.

Papulova, Z., \& Gazova, A. (2016). Role of Strategic Analysis in Strategic DecisionMaking. Procedia Economics and Finance, 39(November 2015), 571-579. https://doi.org/10.1016/s22125671(16)30301-x

Pidarta, M. (2011). Manajemen pendidikan Indonesia. BAndung: Rineka Cipta.

Riyanto, Y. (2007). Metodologi Penelitian Pendidikan Kualitatif dan Kuantitatif. Surabaya: UNESA Universiy Press.

Slavik, J., Putnova, A., \& Cebakova, A. (2015). Leadership as a Tool of Strategic Management. Procedia Economics and Finance, 26(15), 1159-1163. https://doi.org/10.1016/s22125671(15)00946-6 
Muhammad Amin Amrullah, Sri Setyowati, Haris Supratno, Implementasi Manajemen Strategik di Sekolah Unggulan

Sugiyono. (2012). Metode Penelitian Kuantitatif

Kualitatifdan $R \& D$. Bandung: Alfabeta. 